\title{
"Health of the World": The Symbolic Associations of Trees in Eleventh-Century England, in the Context of Landscape
}

\author{
Daniel Ruten*
}

\begin{abstract}
The Christianization of Anglo-Saxon England in the seventh century CE was a momentous period of religious change which had many far-reaching effects. Anglo-Saxon paganism had attached a set of sacred and symbolic meanings to various natural features in the English landscape. In this belief system, trees and groves were strongly associated with healing and defensive powers. This paper will argue that due to the persistent presence of once-sacred trees and groves in the English landscape, combined with a continually widespread demand for health remedies, the pre-Christian associations of trees with healing and defense in England were not easily forgotten after the conversion period and in fact continued throughout the eleventh century. However, these pre-Christian symbolic associations were effectively subsumed within the hegemony of a Christian ideological framework. A continual, bidirectional alignment of these symbolic associations of trees with elements of Christian symbolism, namely that of Paradise and that of the Cross, served to explain and legitimize their syncretic continuation within this Christian framework. These insights invite us to appreciate some of the complexity of the syncretism that occurred during the period of Christian conversion in Anglo-Saxon England. They also invite us to further contemplate some of the lasting effects of this gradual syncretic process.
\end{abstract}

Keywords: Anglo-Saxon England, medieval, cultural, history, health, landscape

The Christian conversion of Anglo-Saxon England was a momentous period of religious change, which was to have a wide range of deeply influential effects. As Marilyn Dunn has noted, it marked the transition from a 'world accepting' religion (i.e. Anglo-Saxon paganism) to a 'world rejecting' religion (Christianity), a stark change in ideological perspective that had significant implications.
Anglo-Saxon paganism had attached a complex set of sacred and symbolic associations to various natural features in localized landscapes. ${ }^{1}$ In this belief system, sacred trees and sacred groves played a prominent role as both

${ }^{1}$ Marilyn Dunn, The Christianization of the Anglo-Saxons c. 597-c. 700: Discourses of Life, Death and the Afterlife (London: Continuum, 2009), 3, 76.

\footnotetext{
*Department of History, College of Arts and Science, University of Saskatchewan, Saskatoon, SK, Canada
} 
objects of veneration and sources of healing and protection. One question to be raised, then, is how the period of Christian conversion in England affected the survival of these pre-Christian sacred and symbolic associations of trees into the late Anglo-Saxon period. This paper aims to answer this question by examining some of the evidence from the eleventh century, mainly in the form of charms, charters, and liturgical texts. In these sources, three key issues become apparent: syncretism, healing, and landscape.

The combination of the persistent presence of once-sacred trees and groves in the English landscape, and a continually widespread demand for health remedies, meant that the pre-Christian associations of trees with healing and defense were not easily forgotten, and in fact continued throughout the eleventh century. However, as charm and literary evidence reveals, these preChristian symbolic associations were effectively subsumed within the hegemony of a Christian ideological framework, which allowed for the healing and defensive powers of trees by positioning them as ultimately deriving from the power of God. A continual, bidirectional alignment of these symbolic associations of trees with elements of Christian symbolism, namely that of Paradise and that of the Cross, served to explain and legitimize their syncretic continuation within the Christian framework. Ultimately, though, exactly how these symbolic associations of trees and groves might have been perceived from the perspective of the different members of the laity remains an open question.

Beliefs in the sacrality of natural features are common to all imagistic religions, and the attachment of sacred and symbolic meanings to trees has historically been a feature of many of these religions. ${ }^{2}$ As historian Della Hooke notes, trees span both downwards and upwards, which has often led them to be viewed as symbolically uniting different worlds. This World Tree symbolism has been a feature of many cultures. ${ }^{3}$ Moreover, sacred

\footnotetext{
${ }^{2}$ Dunn, Christianization, 3, 76. As Dunn notes, religious studies scholars distinguish between 'imagistic' and 'doctrinal' modes of religion. Different religions may combine these modes to different extents; AngloSaxon paganism is said to be a typical example of a religion characterized by the imagistic mode, while early Christianity exemplifies the doctrinal mode.

3 Della Hooke, Trees in Anglo-Saxon England: Literature, Lore and Landscape (Woodbridge: Boydell Press, 2010), 3-4.
}

meanings of trees, including World Tree symbolism, could also be applied to wooden pillars, posts or rods; one example of this is Irminsul, the cosmic pillar said to uphold the world in pagan Saxon beliefs. In this kind of framework, wooden posts could then become sacred symbols of cosmic pillars, objects of veneration in their own right. ${ }^{4}$

In pagan Germanic traditions especially, sacred groves or forest clearings were often where trees or posts were imbued with sacred meanings. Indeed, these kinds of sites devoted to the veneration and/or preservation of sacred trees were widespread across Europe. ${ }^{5}$ Some of these groves contained shrines to different pagan deities, and were the sites of rituals meant to venerate and communicate with the spirit world. ${ }^{6}$ The sacred grove commonly contained three key features: a sacred tree, stone, and water source. Some scholars argue that the sacred grove thus constituted a microcosmic landscape, a representation of the environment in which the stone connoted reality and the unchanging, while the tree symbolized life and renewal. ${ }^{7}$

In pre-Christian Anglo-Saxon England as well, archaeological evidence exists of rituals involving sacred tree veneration or symbolism. This evidence includes findings such as trees or posts protected by enclosures; it appears that the Anglo-Saxons raised numerous sacred pillars. ${ }^{8}$ Additionally, much as in the wider pagan Germanic tradition, the Anglo-Saxons also apparently dedicated specific groves to various pagan deities, including Tiw, Thunor and Woden. Place-name evidence is a major

\footnotetext{
${ }^{4}$ Clive Tolley, "What is a 'World Tree', and Should We Expect to Find One Growing in Anglo-Saxon England?" in Trees and Timber in the Anglo-Saxon World, eds. Michael D.J. Bintley and Michael G. Shapland (Oxford Scholarship Online, 2013), 178-179; Dauksta, "From Post to Pillar - The Development and Persistence of an Arboreal Metaphor," in New Perspectives on People and Forests, eds. E. Ritter and D. Dauksta (Springer Science \& Business Media, 2011), 99, 104.
${ }^{5}$ Hooke, Trees, 5-6.
${ }^{6}$ Hooke, Trees, 6; Dunn, Christianization, 60, 74; Tolley, "What is a 'World Tree," 181.
7 Dauksta, "From Post to Pillar," 106. Dauksta does not provide any theories of what the water source could represent.

${ }^{8}$ Hooke, Trees; Dauksta, “From Post to Pillar," 108.
} 
source of evidence for these sacred associations. ${ }^{9}$ Runic evidence also indicates that specific species of trees held their own sets of symbolic associations in the AngloSaxon worldview. For example, ash seems to have been associated with battle and defense, and significantly, certain types of trees were associated with healing powers, including both ash and alder trees. ${ }^{10}$ Trees could also be associated with healing powers in more generalized ways. For example, one belief held that children could be cured of sicknesses by being passed through a hollow tree. ${ }^{11}$

It is important to place these symbolic associations into their practical context, as trees had an integral place in Anglo-Saxon society. Timber was the single most important building material throughout the Anglo-Saxon period (it is illustrative that the Anglo-Saxon verb meaning "to build" was timbran or timbrian), ${ }_{1}^{12}$ and trees held additional significance as sources of fuel and food. Most pigs were kept in woodland pasture during this period, finding nourishment by eating acorns or fruit from trees. Moreover, particularly distinctive trees in the landscape could become useful landmarks, places of assembly or boundary markers. ${ }^{13}$ Overall, therefore, most AngloSaxon people would have had contact with trees or their products on a daily basis.

The coming of Christianity to Anglo-Saxon England, starting around the late sixth century $C E$, saw attempts to completely displace pagan beliefs. The transition from a 'world accepting' to a 'world rejecting' religion was to have significant implications for the place that trees would hold in the new symbolic order. The new Christian ideology carried with it assumptions of human mastery over nature. In this ideology, animist attributions of souls to trees, or any beliefs in their sacrality, would not be tolerated. Trees, then, would have to shed their sacred associations. Thus on the Continent, prominent sacred trees were attacked or completely destroyed; one

\footnotetext{
${ }^{9}$ Dunn, Christianization, 57-58; Hooke, Trees, 46-47.

${ }^{10}$ Hooke, Trees, 60, 200, 223.

${ }^{11}$ Della Hooke, "Christianity and the 'Sacred Tree," in Trees and Timber in the Anglo-Saxon World, eds. Michael D.J. Bintley and Michael G. Shapland (Oxford Scholarship Online, 2013), 232.

12 Joseph Bosworth, "An Anglo-Saxon Dictionary Online," s.v. "Timbran" (July 16, 2010). http://www.bosworthtoller.com/030511.

${ }^{13}$ Hooke, Trees, 139-141, 96.
}

well-known example is Boniface's felling of the great sacred oak of Gaismer in Germany. ${ }^{14}$ In England, however, a different strategy dominated. In 601, Pope Gregory I famously advised that pagan shrines and sacred sites in England were to be repurposed instead of destroyed, advocating a more gradual process of conversion. There was then a great reluctance to destroy sacred trees and groves throughout the conversion period. ${ }^{15}$

Instead, there was a more gradual redirection of the symbolic associations of trees towards that of the cross. The cross had notably been imagined as a tree, and particularly as a Tree of Life, since early Christian times. It only made sense to emphasize this symbolic blending in the Anglo-Saxon context, as establishing links between paganism and Christianity in this fashion would help ease the transition through the conversion period. ${ }^{16}$ The tree and the cross were thus equated in various ways. One way was through language; the Old English words commonly used for cross all meant 'tree' (e.g., 'treow,' 'rod,' 'beam'). Old English literature then described the cross as "the noblest tree of all," a way to place Christian symbolism in a familiar cultural context while also arguing for its superiority to the older pagan sacred trees. ${ }^{17}$ However, cross and tree could also be equated or blended visually. Crosses were raised across the English landscape, some with features reminiscent of trees. Physically placing crosses in the landscape in this fashion was another means to instill new beliefs in a familiar way, particularly for illiterate populations, by creating a competitor to pagan sacred trees. ${ }^{18}$

By the late seventh century, Christianity had become fairly widely accepted across England, but pagan customs or beliefs did not entirely cease. ${ }^{19}$ There are hints

${ }^{14}$ Dunn, Christianization, 3; Hooke, Trees, 21-23; Barbara Yorke, The Conversion of Britain: Religion, Politics and Society in Britain c. 600-800 (Harlow: Pearson Longman, 2006), 133.

${ }^{15}$ Dunn, Christianization, 56; Hooke, Trees, 41; Yorke, Conversion, 133.

${ }^{16}$ Hooke, Trees, 24, 66; Tolley, "What is a "World Tree," 183; Yorke, Conversion, 133-134.

${ }^{17}$ Richard North, Heathen Gods in Old English Literature (Cambridge: Cambridge University Press, 1997), 277.

${ }^{18}$ Hooke, Trees, 51; Dunn, Christianization, 152, 64. The Ruthwell cross from the 8 th century is a major example of a cross sculpted with organic, tree-like features.

${ }^{19}$ Hooke, Trees, 31. 
that this is true as well for the sacred associations of trees. Della Hooke discusses a particular Anglo-Saxon charter from 854 CE granting lands at Taunton in Somerset. The Old English boundary clause in one copy of the charter refers to a "holy ash" ('halgan aesce'); the Latin version of the same boundary clause in another copy refers to this tree as "an ash tree which the ignorant call holy," indicating that the pagan sacred associations of this ash tree had persisted long after the conversion period. Hooke furthermore argues that there was also a survival of pagan beliefs viewing trees as symbolically linking the earth to the cosmos. ${ }^{20}$ All of this emphasizes that the process of Christian conversion was by no means swift nor absolute, and also begins to suggest that the gradual nature of this process may have lent itself not so much to the replacement of pagan beliefs, as much as to their syncretic subordination. ${ }^{21}$

The evidence of the eleventh century similarly indicates the survival of pre-Christian sacred and symbolic associations of trees, which derives first and foremost from the persistence of these trees and groves in the landscape. This is hinted at by the Laws of the Northumbrian Priests, dating from the early 1020s, as one statute proclaims that

If there is on anyone's land a sanctuary round a stone or a tree or a well or any such nonsense, he who made it is then to pay lahslit, half to Christ and half to the lord of the estate... And if the lord of the estate will not help in the punishment, then Christ and the king are to have the compensation. $^{22}$

This law notably targets the veneration of all three key elements of a sacred grove: tree, stone and well. The inclusion of the additional clause at the end hints that the law was framed to actually prosecute ongoing practises, not merely to discourage them. Similarly, Cnut's laws (also from about 1020) also forbid as "heathen practise" the worshipping of "wells or stones or any kind of forest

20 lbid., 50, 98.

${ }^{21}$ Yorke, Conversion, 136.

22 "The Law of the Northumbrian Priests (probably 1020-1023)." trans. Thorpe, in English Historical Documents vol. 1, c.500-1042, ed. Dorothy Whitelock, doc. 52 (Routledge, 1979) tree, ${ }^{\prime 23}$ suggesting that the survival of pagan rituals venerating trees and sacred groves was a continued source of anxiety for both the Church and the Christian king. ${ }^{24}$ It is likely that these sites of tree veneration were effectively used as rural healing shrines; in his St. Bartholomew's Day Homily, Flfric of Eynsham (c. 955-1010) makes a point of emphasizing that "[i]t is not allowed to any christian man to fetch his health from any stone, nor from any tree, unless it be the holy sign of the rood..." ${ }^{25}$ This passage both hints at the lingering associations of sacred groves and trees with healing powers, and illustrates how the cross was set up as a Christian replacement.

The survival of sacred groves in the English landscape can also be seen by looking at Domesday Book, the comprehensive land survey undertaken during the reign of King William I in 1086. Domesday is a particularly valuable source for the distribution of woodland in late eleventh century England. ${ }^{26}$ Scattered throughout the text of Domesday Book are six recorded "groves," five of which are specified to be "alder-groves." Most of them are less than five acres in size, with the largest one spanning fourteen acres. They are also fairly widely dispersed through England geographically. ${ }^{27}$

23 "Extracts from the Laws of Cnut," trans. Robertson and Thorpe, in English Historical Documents vol. 1, c.500-1042, ed. Dorothy Whitelock, doc. 49 (Routledge, 1979)

${ }^{24}$ This is also the interpretation argued for by Della Hooke: Trees, 50.

${ }^{25}$ Audrey Meaney, "The Practice of Medicine in England about the Year 1000," The Society for the Social History of Medicine vol. 13, no. 2 (2000), 235; Elfric, The Homilies of the Anglo-Saxon Church: Homilies of AElfric vol. 1, trans. Benjamin Thorpe (London: 1844), 475.

${ }^{26}$ Hooke, Trees, 120, 122.

27 J. Palmer, Electronic Edition of Domesday Book: Translation, Databases and Scholarly Commentary, 1086; second edition [data collection] (UK Data Service, 2010): http://dx.doi.org/10.5255/UKDA-SN-5694-1. The recorded locations of these groves, and their corresponding entries in the Phillmore edition of Domesday, are as follows: Dartford (Kent 1.1); Stanton St. Bernard (Wiltshire 13.1); Loxhore (Devonshire 16.68); Ashleigh (Devonshire 17.9); Standon \& Rudge (Staffordshire 11.15); and Burslem (Staffordshire 11.22). 
Alder was one of the species of tree associated with healing in pre-Christian Anglo-Saxon beliefs, as mentioned previously; its bark was used in leechdoms against various ailments. When the bark is cut off of an alder tree, the dark, crimson-tinged sap flows readily. It thus has been seen as akin to bleeding, an anthropomorphism which could encourage the associations of the tree with mystical or sacred meanings. In the realm of Irish legend, for example, the first man was said to have been formed from an alder tree. ${ }^{28}$ It is difficult to substantiate sacred origins for all of the alder groves mentioned in Domesday, but one case study can possibly provide some hints.

In Domesday, Stanton St. Bernard in Wiltshire is said to contain a three-acre alder grove, surrounded by meadows and pasture. This area corresponds to that described in three earlier Anglo-Saxon charters: S 368 (c. 903 (E), S 647 (c. 957), and S 685 (c. 960). Notably, the Old English boundary clauses of all three charters mention a "blacan graf" or "blacan grafum.." ${ }^{29}$ This could mean one of several things. The nominative singular form of this phrase, blaca graf, can be translated alternately as "black grove," "white grove" or "burnt grove." ${ }^{10}$ However, there is good reason to take the phrase to mean "black grove" in this context. Alder trees were strongly associated with the colour black due to their blackish cones, and were thus often called "the black alder. ${ }^{\prime \prime 1}$ Therefore, these charters are most likely describing an alder grove as a

\footnotetext{
${ }^{28}$ Hooke, Trees, 223.

29 "Grant by King Edward to the Prince Ordlaf, of land at Stantun, or Stanton, co. Wilts. AD. 903," in Cartularium Saxonium: A Collection of Charters Relating to AngloSaxon History, ed. Walter de Gray Birch (London: Whiting \& co., 1887), 253-254 ; “S 647, A.D. 957. King Eadwig to Oswulf, bishop; grant of 20 hides (mansae) at Stanton St Bernard, Wilts." The Electronic Sawyer. http://www.esawyer.org.uk/charter/647.html. ; "S 685, A.D. 960. King Edgar to Oswulf, bishop; grant of 20 hides (mansae) at Stanton St Bernard, Wilts." The Electronic Sawyer.

http://www.esawyer.org.uk/charter/685.html.

30 Dictionary of Old English: $A$ to $H$ online, ed. Angus Cameron, Ashley Crandell Amos, Antonette diPaolo Healey et al., s.v. "blaec" and "blāc" (Toronto: Dictionary of Old English Project, 2016).

31 Hooke, Trees, 223.
}

"black grove," which would correspond to the alder grove described in Domesday Book.

The sacrality of this grove is suggested by the wider context of the landscape. A "holan pelle" (holy well or spring) is mentioned in close proximity to the grove in all three charters. The role of a water source as one of the three key elements of a sacred grove has been mentioned previously. Della Hooke additionally notes that trees were sometimes explicitly associated with holy wells or springs through place names, such as Ashwell at Glastonbury. ${ }^{32}$ In the case of the charter from 854 CE at Taunton already discussed, the boundary clause also mentions a "halgan pelle" in close proximity to the holy ash, ${ }^{33}$ further indicating a close relationship between sacred trees and sacred wells. Therefore, it is not difficult to imagine that this alder grove at Stanton St. Bernard may have served as the site of exactly the sort of local healing shrine that $Æ$ Elfric had tried to discourage, featuring a sacred well and, possibly, a corresponding sacred tree.

Additionally, the boundary clauses of the three Stanton St. Bernard charters mention "wodnes dic" (Woden's dike) in the general vicinity of the alder grove. ${ }^{34}$ This major earthworks feature still carries the name Wansdyke today, and so it certainly would have carried the name at the time of Domesday Book. Woden was likely worshipped as a god by the Anglo-Saxons, especially in Southern England, in the seventh century CE. Although belief in Woden was apparently dying out in England by the eighth century, his memory lived on; notably, multi-

32 Ibid., 41; Della Hooke, "The Sacred Tree in the Belief and Mythology of England," in Sacred Species and Sites: Advances in Biocultural Conservation, eds. Gloria Pungetti, Gonzalo Oviedo and Della Hooke (Cambridge: Cambridge University Press, 2012), 313.

33 "Grant by Adelwulf, King of the West Saxons, to Winchester Cathedral, of land near Taunton... AD 854." In Cartularium Saxonium: A Collection of Charters Relating to Anglo-Saxon History, ed. Walter de Gray Birch (London: Whiting \& co., 1887), 74.

34 "Grant by King Edward to the Prince Ordlaf, of land at Stantun, or Stanton, co. Wilts. AD. 903," 254 ; "S 647, A.D. 957. King Eadwig to Oswulf, bishop; grant of 20 hides (mansae) at Stanton St Bernard, Wilts." ; "S 685, A.D. 960. King Edgar to Oswulf, bishop; grant of 20 hides (mansae) at Stanton St Bernard, Wilts." 
ple Anglo-Saxon kings in the post-conversion period continued to trace their royal lineages back to Woden. ${ }^{35}$

Together, all of these features suggest the pagan heritage of the area of Stanton St Bernard and the sacred associations of the landscape, including the alder grove. The apparent continuity of this alder grove over more than 180 years (from the 903 charter to Domesday c. 1086) is significant in this context, as it illustrates how natural features with traditional sacred associations persisted in landscape long after Christianity had ostensibly replaced pagan customs and beliefs. Particularly in the context of a local landscape with features named after pagan deities, this could encourage the sacred associations of trees and groves to persist in the consciousness of the people who lived in the area. The persistence of the "holy well" in the area as late as 960 CE suggests the continuity of these sacred associations, and furthermore hints at possible associations with healing powers. In the context of a time when medical knowledge was significantly limited, these sorts of sacred groves as sites of healing would have likely been of great importance to the people living in the local area. ${ }^{36}$ All of this invites us to ask what these continued symbolic associations of trees and groves with healing powers may have looked like in practical terms. And in order to understand this, we must turn to some of the literary evidence from the eleventh century.

The surviving literary evidence suggests that the pre-Christian symbolic associations of trees with both healing and defensive powers survived well into the 11th century in England, but they were mostly subsumed within the hegemony of a Christian ideological framework. In other words, this is a case of syncretism at work. Multiple examples of this syncretic integration of pre-Christian healing associations can be found in the Lacnunga, a manuscript dating to about $1050 \mathrm{CE}$ containing various charms and remedies that was likely produced in a monastic context. ${ }^{37}$ One of these charms, the so-called "Benedictio Herbarum," helps explain the subordination of trees' healing powers into a Christian framework:

35 North, Heathen Gods, 79-80; William A. Chaney, "Paganism to Christianity in Anglo-Saxon England," The Harvard Theological Review, Vol. 53, No. 3 (July 1960), 200.

${ }^{36}$ Dunn, Christianization, 76.

37 Karen Louise Jolly, "Anglo-Saxon Charms in the Context of a Christian Worldview," Journal of Medieval History vol. 11 (1985), 287.
Omnipotent eternal God who from the beginning of the world instituted and created all things, both trees after their kind and herbs with their seeds, with which by your benediction you have blessed and ordained the same; now deign with thy benediction to sanctify and bless these plants and other fruits, so that they may confer health of mind and body to those partaking (of them), and a safeguard of defense and eternal life. ${ }^{38}$

In this charm, the pre-Christian associations of trees with healing and defensive powers are allowed for, but are subsumed within a Christian framework, wherein these powers are said to ultimately derive from the power of God. By integrating and subordinating beliefs in the healing powers of trees into the Christian spiritual hierarchy, charms could then become viewed as consistent with a Christian worldview, despite any remaining 'pagan' elements. ${ }^{39}$

Similar themes can also be seen in another Lacnunga charm "against flying venom," which could possibly mean some kind of infectious disease..$^{40}$ As a remedy, it first prescribes:

slash four strokes in the four quarters with an oaken brand; make the brand bloody, throw it away; sing this on it three times: [making the sign of the cross as drawn in the manuscript]... ${ }^{41}$

A distinctly Christian prayer follows. The initial slashing of one's limbs with an 'oaken brand' hints at the pagan origins of the charm, with the specification of the type of

38 "Lacnunga CXCI Benedictio Herbarum," trans. Karen Louise Jolly. University of Hawaii. http://www2.hawaii.edu/ kjolly/lacnunga.htm.

${ }^{39}$ Audrey Meaney, L. "Extra-Medical Elements in AngloSaxon Medicine," Social History of Medicine Vol. 24, No. 1 (2011), 41; Jolly, “Anglo-Saxon Charms,” 279.

40 Meaney, "Extra-Medical Elements in Anglo-Saxon Medicine," 46.

41 “Lacnunga CXXXIII (74)," trans. Karen Louise Jolly. University of Hawaii.

http://www2.hawaii.edu/ kjolly/lacnunga.htm. 
wood being a particularly significant indicator. The oak was the single most important and venerated tree in the sacred groves of Germanic pagans; it was also the tree sacred to Thunor, the thunder god..$^{42}$ Making the oak branch bloody and then throwing it away likely symbolizes a removal of the disease from the patient. ${ }^{43}$ The addition of Christian elements, namely the prayer and the sign of the cross, serves to legitimize the symbolic rituals of the charm by situating them in the Christian framework. Some of the words may change, but the actions largely remain the same, and so in this way the pagan symbolic associations of the 'oaken brand' with healing ultimately survive within a Christian context. ${ }^{44}$

More cryptically, another charm in the Lacnunga calls for a particularly obscure tree-related ingredient:

Against the bite of an adder. If he obtains and eats bark which comes from Paradise, no poison can hurt him. - Then he that wrote this book remarked that it was difficult to get. ${ }^{45}$

As Audrey Meaney remarks, is not clear whether this "bark from Paradise" is magic, or perhaps some kind of exotic herb. ${ }^{46}$ But either way, this charm combines preChristian and Christian symbolism in a way that is significantly different from the other Lacnunga charms examined thus far. Unlike the "flying venom" charm, this does not appear to be a distinctly pagan charm at its core, to which some Christian elements were merely tacked on at a later date. The general construction of the charm seems to reflect the symbolism of Christian doctrine: the poison of a snake, the great symbol of evil that helped cause Man's downfall from Paradise, can only be warded off by the bark of a tree that originates from the same place. This also suggests classic Tree of Life symbolism, in that the death brought by poison can only be avoided if one can manage to find the ever-elusive original source of life. At the same time, though, the prescription of tree bark as an ingredient with healing powers if ingested is a feature

\footnotetext{
42 Hooke, Trees, 193; Dunn, Christianization, 75.

43 Meaney, “Extra-Medical Elements," 46.

44 Jolly, “Anglo-Saxon Charms," 286.

45 “Lacnunga no. 81," trans. Godfrid Storms, in Storms, Anglo-Saxon Magic (New York: Gordon Press, 1974), 73.

46 Meaney, “Extra-Medical Elements," 47.
}

that is more reminiscent of traditional, pre-Christian Anglo-Saxon remedies, such as the use of alder bark in charms against various maladies. ${ }^{47}$ This suggests the syncretic alignment of pre-Christian conceptions of the healing powers of trees and groves with the symbolism of Christian doctrine in what might be spells created after Christianization. To gain a fuller understanding of how the healing powers of trees and groves were reconceptualized in the Christian framework, we must now turn to a very different source from the eleventh century: The Elucidarius of Honorius Augustodunensis.

The Elucidarius is a text which was written in England by one Honorius Augustodunensis; it likely dates from sometime between 1096 and 1100 . Originally written in Latin, the text consists of a dialogue between 'master' and 'pupil' that seeks to make clear the central tenets of Christianity. ${ }^{48}$ As a didactic tool, it was intended to anticipate and provide answers to various doctrinal questions, for the purposes of the clergy who would field such questions from the laity. The work quickly became exceedingly popular for its time, among both the clergy and the laity. ${ }^{49}$ The text is particularly notable for its description of Paradise:

My childe, Paradise is a place moste merieste in the est, in the whiche place ther growen dyuerse trees of kynde which bere frutis of grete vertu ayenst dyuerse sikenesses... ${ }^{\circ}$

It is highly significant that the text explicitly associates the trees in Paradise with healing powers against "dyu-

\footnotetext{
${ }^{47}$ Hooke, Trees, 223.

${ }^{48}$ Valerie I.J. Flint, “The 'Elucidarius' of Honorius Augustodunensis and Reform in Late Eleventh Century England." Revue Bénédictine vol. 85, no. 1-2 (January 1975), 179 ; C.W. Marx, “An Abbreviated Middle English Prose Translation of the Elucidarius," Leeds Studies in English, vol. 31 (2000), 1.

${ }^{49}$ Flint, “'Elucidarius,” 187, 189; Marx, “Abbreviated Middle English Prose Translation," 2.

${ }^{50}$ NLW Peniarth 12, fols. 1r-11r, in Marx, "Abbreviated Middle English Prose Translation," 28. The version I am relying on for my analysis is that found in the Peniarth 12 manuscript; it is an abbreviated Middle English translation of the original which likely dates from around the late fifteenth century.
} 
erse sikenesses." It is particularly interesting in the context of the other aspects of Paradise that are described namely its representation as a place physically located in the East that still exists. The Latin original too describes Paradise with these same basic features, including trees with fruits to remedy various maladies..$^{51}$ This representation of Paradise as a place still existing on the Earth, with trees imbued with healing powers, essentially presents it as a sacred grove if viewed in the Anglo-Saxon cultural context - not only a sacred grove, but the original sacred grove. This description could then possibly serve to legitimize the continuation of pre-Christian beliefs regarding the healing powers of certain trees and groves in the Christian framework. It could also help to contextualize the Lacnunga charm discussed above; if Paradise is still located somewhere on Earth, and it has many trees with healing powers, then it would only make sense that eating some of the bark from one of those trees would help in a case where no other remedies could.

Furthermore, this description invites us to consider more of the practical context, and particularly some of the social factors that also helped to encourage the survival of these associations of trees with healing in the Christian framework. The clergy was expected to meet the demands of people for healing in England at this time. Christianizing traditional pre-Christian rituals was a way for them to better meet these widespread demands, as charms offered hope for ailments that known medicine at the time could not do much about. ${ }^{52}$ Ideologically, then, the description of Paradise in the Elucidarius works along similar lines: it offers a far-off, ideal vision of hope for those who suffer, while also further legitimizing the integration of pre-Christian beliefs and rituals about healing powers of groves and trees into the Christian worldview. The corresponding Lacnunga charm offers the same distant sense of hope - if one can only track down this incredibly elusive piece of tree bark, they can attain a perfect form of healing.

This survival of trees' healing associations was likely also aided by the continued symbolic equation of cross and tree. This equation is evident in the Elucidarius. At one point the pupil asks, "For what cause wolde Criste

${ }^{51}$ Wanda Cizewski, "The Doctrine of Creation in the First Half of the Twelfth Century: Selected Authors" (PhD Diss., University of Toronto, 1983), 116.

52 Yorke, Conversion, 249; Meaney, "Practice," 229, 234; Jolly, “Anglo-Saxon Charms," 291; Dunn, Christianization, 76. dye vpon a tre?," to which the master responds by drawing a parallel between the tree that caused Man's downfall (in Paradise) and the tree which then allowed his salvation (the cross). ${ }^{53}$ Notably, visual representations of the cross in the eleventh century also blended the cross with the tree, suggesting Tree of Life symbolism; this can be seen in multiple illustrations in English manuscripts wherein the cross is depicted as a green tree. ${ }^{54}$ Additionally, some eleventh-century prayers suggest this equation while also associating the cross with healing. One prayer in particular, found in Aelfwine's Prayerbook (c. mideleventh century), notably describes the cross's wood as "green" while also praising it for allowing the "health of the world" to be made (i.e. through Christ). ${ }^{55}$ It seems possible that the continued symbolic blending of cross and tree, combined with simultaneous associations of the cross with healing, could potentially have encouraged associations of trees with healing to survive in the social context.

Most significantly of all, though, the description of Paradise in the Elucidarius suggests that the syncretic alignment of pre-Christian symbolic associations of trees with healing in the Christian framework was to some extent bidirectional - showing that not only could pagan elements (such as those found in charms) be changed or elaborated on to better fit with Christian doctrine and ideology, but also that Christian doctrines could be changed or elaborated on as well, in order to better accommodate and legitimize these pre-Christian associations in a Christian ideological framework. As discussed, this continuation of pre-Christian symbolic associations of trees with healing powers within the Christian context throughout the eleventh century was fundamentally driven by two key contextual factors: first, the pervasive soci-

\footnotetext{
${ }^{53}$ NLW Peniarth 12, fols. 1r-11r, in Marx, "An Abbreviated Middle English Prose Translation of the Elucidarius," 30 .

54 Thomas N. Hall, "The Cross as a Green Tree in the Vindicta Salvatoris and the Green Rod of Moses in Exodus." English Studies vol. 4 (1991), 300-302.

${ }^{55}$ London, British Library, Cotton titus D. xxvi + xxvii), fol. 67v, trans. Christopher Vaccaro, in "Crux christi/cristes rod: Interpreting the Anglo-Saxon Cross" (PhD diss., City University of New York, 2003), 158 ; Christopher Vaccaro, "Crux christi/cristes rod: Interpreting the Anglo-Saxon Cross" (PhD diss., City University of New York, 2003), 22, 25; Vaccaro notes that this theme of "cross as remedy" was a common one at this time.
} 
etal demand for healing remedies, and second, the persistent presence of sacred groves and trees in the English landscape. These insights invite us to appreciate some of the complexity of the symbolic syncretism that occurred during the period of Christian conversion in Anglo-Saxon England. They also invite us to further contemplate some of the lasting effects of this syncretic process, through the eleventh century and beyond.

\section{Bibliography}

Chaney, William A. "Paganism to Christianity in AngloSaxon England." The Harvard Theological Review, Vol. 53, No. 3 (July 1960): 197-217.

Cizewski, Wanda. "The Doctrine of Creation in the First Half of the Twelfth Century: Selected Authors." PhD Diss., University of Toronto, 1983.

Dauksta, Dainis. "From Post to Pillar - The Development and Persistence of an Arboreal Metaphor." In New Perspectives on People and Forests, edited by E. Ritter and D. Dauksta, 99-117. Springer Science \& Business Media, 2011.

Dunn, Marilyn. The Christianization of the Anglo-Saxons C. 597-c. 700: Discourses of Life, Death and the Afterlife. London: Continuum, 2009.

"Extracts from the Laws of Cnut." Translated by Robertson and Thorpe, in English Historical Documents vol. 1, c.500-1042, edited by Dorothy Whitelock, document 49. Routledge, 1979.

Flint, Valerie I.J. "The 'Elucidarius' of Honorius Augustodunensis and Reform in Late Eleventh Century England." Revue Bénédictine vol. 85, no. 1-2 (Janvary 1975): 190-198.

"Grant by Adelwulf, King of the West Saxons, to Winchester Cathedral, of land near Taunton... AD 854." In Cartularium Saxonium: A Collection of Charters Relating to Anglo-Saxon History, edited by Walter de Gray Birch, 73-74. London: Whiting \& co., 1887.

"Grant by King Edward to the Prince Ordlaf, of land at Stantun, or Stanton, co. Wilts. AD. 903." In Cartularium Saxonium: A Collection of Charters Relating to Anglo-Saxon History, edited by Walter de
Gray Birch, 253-254. London: Whiting \& co., 1887.

Hall, Thomas N. "The Cross as a Green Tree in the Vindicta Salvatoris and the Green Rod of Moses in Exodus." English Studies vol. 4 (1991): 297-307.

Hooke, Della. "Christianity and the 'Sacred Tree."' In Trees and Timber in the Anglo-Saxon, edited by Michael D.J. Bintley and Michael G. Shapland, 228-247. Oxford Scholarship Online, 2013.

Hooke, Della. "The Sacred Tree in the Belief and Mythology of England." In Sacred Species and Sites: Advances in Biocultural Conservation, edited by Gloria Pungetti, Gonzalo Oviedo and Della Hooke, 307-321. Cambridge: Cambridge University Press, 2012.

Hooke, Della. Trees in Anglo-Saxon England: Literature, Lore and Landscape. Woodbridge: Boydell Press, 2010.

Jolly, Karen Louise. "Anglo-Saxon Charms in the Context of a Christian Worldview." Journal of Medieval History vol. 11 (1985): 279-293.

"Lacnunga CXCl Benedictio Herbarum." Translated by Karen Louise Jolly. University of Hawaii. http://www2.hawaii.edu/ kjolly/lacnunga.htm.

"Lacnunga CXXXIII (74)," translated by Karen Louise Jolly. University of Hawaii. http://www2.hawaii.edu/ kjolly/lacnunga.htm.

London, British Library, Cotton titus D. xxvi + xxvii), f. 67v, translated by Christopher Vaccaro. In "Crux christi/cristes rod: Interpreting the Anglo-Saxon Cross," 158. PhD diss., City University of New York, 2003.

Marx, C.W. "An Abbreviated Middle English Prose Translation of the Elucidarius." Leeds Studies in English, vol. 31 (2000): 1-53.

Meaney, Audrey. "The Practice of Medicine in England about the Year 1000." The Society for the Social History of Medicine vol. 13, no. 2 (2000): 221-237.

Meaney, Audrey L. "Extra-Medical Elements in AngloSaxon Medicine." Social History of Medicine Vol. 24, No. 1 (2011): 41-56. 
North, Richard. Heathen Gods in Old English Literature. Cambridge: Cambridge University Press, 1997.

Palmer, J. Electronic Edition of Domesday Book: Translation, Databases and Scholarly Commentary, 1086; second edition. [data collection]. 2nd Edition. UK Data Service, 2010. http://dx.doi.org/10.5255/UKDA-SN-5694-1.

"S 647, A.D. 957. King Eadwig to Oswulf, bishop; grant of 20 hides (mansae) at Stanton St Bernard, Wilts." The Electronic Sawyer. http://www.esawyer.org.uk/charter/647.html.

"S 685, A.D. 960. King Edgar to Oswulf, bishop; grant of 20 hides (mansae) at Stanton St Bernard, Wilts." The Electronic Sawyer. http://www.esawyer.org.uk/charter/685.html.

Storms, Godfrid. Anglo-Saxon Magic. New York: Gordon Press, 1974 .

"The Law of the Northumbrian Priests (probably 10201023)." Translated by Thorpe, in English Historical Documents vol. 1, C.500-1042, edited by Dorothy Whitelock, document 52. Routledge, 1979.

Tolley, Clive. "What is a 'World Tree', and Should We Expect to Find One Growing in Anglo-Saxon England?" In Trees and Timber in the Anglo-Saxon World, edited by Michael D.J. Bintley and Michael G. Shapland, 177-184. Oxford Scholarship Online, 2013.

Vaccaro, Christopher. "Crux christi/cristes rod: Interpreting the Anglo-Saxon Cross." PhD diss., City University of New York, 2003.

Yorke, Barbara. The Conversion of Britain: Religion, Politics and Society in Britain c. 600-800. Harlow: Pearson Longman, 2006. 
Trees and Healing in Eleventh-Century England (Ruten)

University of Saskatchewan Undergraduate Research Journal 